\title{
Pneumonia associated with invasive mechanical ventilation: nursing care
}

Pneumonia associada à ventilação mecânica invasiva: cuidados de enfermagem

Neumonía asociada a la ventilación mecánica invasiva: cuidados de enfermería

João Ricardo Miranda da Cruz*iD; Matilde Delmina da Silva Martins** (D)

\begin{abstract}
Background: Ventilator-associated pneumonia is an infection susceptible to prevention with the compliance of measures (bundle), whose prevention is a huge challenge for nursing practice.

Objectives: To identify nursing procedures in patients undergoing invasive mechanical ventilation and the development of pneumonia in intensive care medicine.

Methods: Longitudinal and descriptive study carried out in the Intensive Care Unit of a hospital in the north of Portugal, between $01 / 11 / 2017$ and 28/02/2018, with a sample of 20 nurses and a total of 102 observations. The data collection instrument used was a questionnaire for the characterization of the sample and a grid of direct observation. Data were entered and analyzed using Microsoft Excel 2016.

Results: The verification of the cuff pressure and the aspiration of secretions were the procedures with lower participation. A $0.3 \%$ rate of ventilator-associated pneumonia occurred.

Conclusion: The frequency of pneumonia in ventilated patients was low, as there was a high rate of adherence to the bundle.
\end{abstract}

Keywords: pneumonia, ventilator-associated; critical care; nursing care; prevention and control

\section{Resumo}

Enquadramento: A pneumonia associada à ventilação mecânica é uma infeção passível de prevenção com o cumprimento de medidas (bundle) e a sua prevenção constitui um grande desafio para a prática de enfermagem.

Objetivos: Identificar os procedimentos de enfermagem em doentes submetidos a ventilação mecânica invasiva e o desenvolvimento de pneumonia num serviço de medicina intensiva.

Metodologia: Estudo longitudinal e descritivo realizado no serviço de Medicina Intensiva de um hospital do norte de Portugal, entre 01/11/2017 a 28/02/2018, com uma amostra de 20 enfermeiros e um total de 102 observaçóes. $\mathrm{O}$ instrumento de recolha de dados utilizado foi um questionário para a caracterização da amostra e uma grelha de observaçáo direta. Os dados foram introduzidos e analisados através do Microsoft Excel 2016.

Resultados: A verificação da pressão do cuffe a aspiração de secreçôes foram os procedimentos que registaram menor adesão. Verificou-se uma taxa de pneumonia associada à ventilação de $0,3 \%$.

Conclusão: A frequência de pneumonia nos doentes ventilados foi baixa, verificando-se uma elevada taxa de adesão à bundle.

Palavras-chave: pneumonia associada à ventilação mecânica; cuidados críticos; cuidados de enfermagem; prevençáo e controle

\footnotetext{
*MSc., RN, Northeast Health Local Unit - Hospital Unit of Bragança, 5301-852, Bragan-

ça, Portugal [j_r_cruz@sapo.pt]. (1) https://orcid.org/0000-0002-4316-481X. Contribution to the article: bibliographical research, data collection, statistical assessment and treatment, data analysis and discussion, writing of the article. Address for correspondence: Avenida das Forças Armadas, n⿳0 $12,5^{\circ}$ Esq., 5300-440, Bragança, Portugal. **Ph.D., Adjunct Professor, Health School, Polytechnic Institute of Bragança, 5300-121 Bragança, Portugal [matildemartins@ipb.pt]. Health Sciences Research Unit (UICISA). (D https://orcid.org/0000-0003-2656-5897. Contribution to the article: statistical data analysis, discussion of results, overall revision of the article.
}

Revista de Enfermagem Referência

\section{Resumen}

Marco contextual: La neumonía asociada a la ventilación mecánica es una infección que se puede prevenir si se cumplen unas medidas (bundle). Su prevención constituye un gran desafío para la práctica de enfermería.

Objetivos: Identificar los procedimientos de enfermería en pacientes sometidos a la ventilación mecánica invasiva con desarrollo de neumonía en un servicio de medicina intensiva.

Metodología: Estudio longitudinal y descriptivo realizado en el servicio de Medicina Intensiva de un hospital del norte de Portugal, entre el 1/11/2017 y el 28/2/2018, con una muestra de 20 enfermeros y un total de 102 observaciones. El instrumento de recogida de datos utilizado fue un cuestionario para caracterizar la muestra y una tabla de observación directa. Los datos se introdujeron y se analizaron a través del Microsoft Excel 2016.

Resultados: La verificación de la presión del brazalete (cuff) y la aspiración de secreciones fueron los procedimientos que registraron menor adhesión. Se verificó una tasa de neumonía asociada a la ventilación del 0,3\%.

Conclusión: La frecuencia de neumonía en los pacientes ventilados fue baja, y se verificó una elevada tasa de adhesión a la bundle.

Palabras clave: neumonía asociada al ventilador; cuidados críticos; atención de enfermería; prevención y control

Received for publication: 12.06 .18

Accepted for publication: 30.10 .18

Série IV - n. ${ }^{\circ} 20$ - JAN./FEV./MAR. 2019 


\section{Introduction}

Considering the technical-scientific advances in the field of intensive medicine, there is a multiplicity of invasive life support instruments that are crucial to critically ill patients, however, they interfere with the natural mechanisms of the organism's defense, forcing the health professional to possess knowledge and skills aimed at minimizing all the inherent risks (Padoveze, Dantas, \& Almeida, 2010).

The invasive mechanical ventilation (IMV) is a means of life support used in the intensive care unit (ICU), consisting of a method that assists or replaces the patient's spontaneous breathing by the action of a fan, which artificially connects to the patient, either by an endotracheal tube or a tracheostomy.

Ventilator-associated pneumonia (VAP) represents one of the more common healthcare-associated infections (HAI) in the ICU (Guillamet \& Kollef, 2015).

Given the importance and complexity of the health problem, the implementation of interventions that affect the prevention of VAP becomes crucial, causing the reduction of infection occurrences, so preventive measures must be adopted. The use of these recommendations (bundles) aims to reduce the variability of practices in which their interventions are based on the best scientific evidence, resulting in the reduction of incidence rates, the improvement of care, and, consequently, better prognosis of critically ill patients.

The general objective of this study is to identify the nursing procedures in patients submitted to IMV and the development of pneumonia in the ICU.

\section{Background}

Critically ill patients require a set of technical means and invasive procedures for diagnosis and therapy for the restoration and maintenance of their vital functions, which makes it susceptible to acquire a care-related infection. Therefore, according to the Institute for Healthcare Improvement (IHI, 2008), pneumonia is associated with ventilation if the patient is intubated and under IMV at the time of diagnosis or in the 48 hours preceding the onset of symptoms.
As regards the IMV, this is one of the techniques to support the maintenance of vital functions of a person in a critical situation, including the introduction of an endotracheal tube in the airway (intubation or tracheostomy), which may lead, thus, to some associated risks due to its invasive nature.

The natural defense mechanisms of the sick when subjected to IMV is modified, often diminished by previous personal history. There is the abolition of the protection of the upper airways, due to the presence of the endotracheal tube, which causes changes in the normal respiratory physiology during the IMV, inducing a pulmonary hypersecretion, as well as an increase in the frequency of respiratory infections, predisposing to a high rate of morbidity and mortality (Pombo, Almeida, \& Rodrigues, 2010).

Strategies for prevention of VAP are of vital importance, the interventions outlined are based on sets of prevention measures, known as bundles, in which those specific recommendations should be implemented in a coordinated manner, subject to systematic monitoring, with recourse to audits, and accompanied by awareness-raising and training of the professionals involved (Tablan, Anderson, \& Besser, 2004). The Directorate General for Health (Direção-Geral de Saúde [DGS], 2016), in its report entitled Prevention and Control of Infections and Antimicrobial Agents in Numbers, emphasizes that VAP is the most frequent HAI in the ICU, whose rate of VAP in Portugal in the year of 2014 was $7.1 \%$ (pneumonia associated with tracheal intubation by 1000 days). Thus, it causes a significant impact on the health services, particularly by lengthening the time of hospitalization in the ICU and extending the time of IMV, and consequently increasing the costs to the health institution.

In Portugal, the DGS issued in 2015 a regulation on interventions bundle of VAP prevention, which included several measures: review, reduce, and, if possible, stop the sedation daily, maximizing the titration of its level to the appropriate minimum for the treatment; discuss and evaluate daily the possibility of weaning off mechanical ventilation and/or extubation, with the daily formulation of weaning plan/ extubation; to keep the head of the bed at an angle equal to or greater than $30^{\circ}$ and to avoid 
moments of supine position. Thirdly, to perform oral hygiene with chlorhexidine gluconate at $0.2 \%$, at least three times per day, in all patients, who expected to remain in the ICU for over 48 hours; to maintain ventilatory circuits clean, replacing them only when visibly soiled or not working. The cuff pressure is measured from 4 to 4 hours, keeping it between 20-30 $\mathrm{cm} \mathrm{H}_{2} \mathrm{O}$ (or $2 \mathrm{~cm} \mathrm{H}_{2} \mathrm{O}$ above the peak inspiratory pressure).

According to Berwick (2014), the analysis of the data provided by the IHI for hospitals that have implemented the bundle concluded that the rates of VAP reduced up to $40 \%$.

Of all the measures of VAP prevention, the most used, according to the literature, are those arising from the provision of care performed by nurses. Gallagher (2012) emphasizes that nurses play a predominant role in the multidisciplinary team, stressing the high importance in the field of healthcare, as well as the necessary training as a way of raising awareness and contributing decisively to the prevention, based on the practice evidence of nursing care. These precautions, in turn, are based on quality and safety, on the etiology and pathophysiology of VAP, thus becoming an excellent measure to prevent VAP in the sick person (Gonçalves, Brasil, Ribeiro, \& Tipple, 2012).

\section{Research Question}

What are the procedures performed by nurses who operate in the intensive care unit of a hospital in the north of Portugal for the prevention of pneumonia associated with the ventilated patient?

\section{Methodology}

This study is longitudinal and descriptive, carried out in the ICU of a hospital in the north of Portugal, between 01/11/2017 and $28 / 02 / 2018$. The sample was composed of 20 nurses, who represent $83.3 \%$ of the total nursing team, which performs its duties in the unit, and in the study period, 102 procedures were performed in ventilated patients.

The data collection instrument used was a questionnaire comprising 10 closed questions, drafted by the researcher, for the characterization of the sample, which includes: age, gender, academic and professional qualifications, professional experience, and training in the area of VAP prevention, and perception of the knowledge that each element of the sample holds on the subject. The questionnaire was delivered in a sealed envelope to each one of the nurses and collected in the same way by the nurse-in-chief of the unit.

For the registration of nursing procedures to the ventilated patient, a grid of direct observation was used, consisting of six dichotomist items, drawn up based on the interventions bundle for the prevention of intubation-associated pneumonia adapted from the Regulation $021 / 2015$ of the DGS, last updated on $30 / 05 / 2017$. Therefore, this instrument data collection comprises the following guidelines: elevation of the patient's head, oral hygiene, aspiration of secretions, ventilatory circuits, pressure of the tube's cuff; "when grouped and implemented in an integrated manner, these guidelines promote the best result, generating a more significant impact than the mere addition of the effect of each of the interventions individually" (DGS, 2015, p. 5). An intervention regarding hand hygiene was added, given the importance and relevance, this practice has in preventing all HAI, notably VAP. The data collection of the grid of direct observation was performed in three shifts (morning, afternoon, and evening), in the first care in which the nurse applies the interventions bundle for the prevention of VAP patients with IMV. The elements that were training in the intensive care department of the Northeast Health Local Unit and attending the Master's course of Medical-Surgical Nursing of the Polytechnic Institute of Bragança - Health School of Bragança collaborated for the implementation of direct observations, in addition to those performed by the author of this study. The behaviors, which were to be observed and recorded, were previously explained in a precise manner.

Data regarding the frequency of pneumonia in ventilated patients in the ICU of ULSNE - Hospital Unit of Bragança, referring to the period of the study, were supplied by the director of the service. These data originated from the Local Control Group (GCL) - National Program for the Prevention and Control 
of Infections and Antimicrobial Resistance (PPCIRA).

The study was submitted for the assessment and authorization by the president of the Administration Board, reference N/REF 117 11-15;14 006491 on 25 October 2017. All participants in the study were voluntary, each one having signed the declaration of consent.

The collected data were analyzed using the program Microsoft Excel 2016, which calculated the absolute and relative frequencies for the ordinal variables.

\section{Results}

The sample was composed of 20 nurses, mostly female $(75 \%)$, aged between 30 and 39 years $(50 \%)$, with a college degree (30\%) and specialized training in nursing (40\%). Fifteen percent of the latter were specialized in medical-surgical nursing and $15 \%$ in rehabilitation, having worked actively in nursing for 20 years or more $(50 \%)$ and in the ICU for less than five years and in equal proportion for more than ten years $(45 \%$; Table 1$)$.

Table 1

Distribution of participants by gender, age, academic qualifications, specialization field, working period, and working period in the ICU $(n=20)$

\begin{tabular}{|c|c|c|c|}
\hline & & $N$ & $\%$ \\
\hline \multirow{2}{*}{ Gender } & Female & 15 & 75 \\
\hline & Male & 5 & 25 \\
\hline \multirow{3}{*}{ Age } & 30 to 39 years & 10 & 50 \\
\hline & 40 to 49 years & 8 & 40 \\
\hline & 50 or older & 2 & 10 \\
\hline \multirow{7}{*}{$\begin{array}{l}\text { Academic } \\
\text { Qualifications }\end{array}$} & Undergraduate & 6 & 30 \\
\hline & Specialization & 1 & 5 \\
\hline & Postgraduate degree & 4 & 20 \\
\hline & Master's degree & 2 & 10 \\
\hline & Specialization and postgraduate degree & 4 & 20 \\
\hline & Specialization and master's degree & 2 & 10 \\
\hline & Specialization, postgraduate, and master's degree & 1 & 5 \\
\hline \multirow{10}{*}{$\begin{array}{l}\text { Specialization } \\
\text { Field }\end{array}$} & Medical-surgical & 3 & 15 \\
\hline & Intensive care & 1 & 5 \\
\hline & Bioethics & 1 & 5 \\
\hline & Rehabilitation & 3 & 15 \\
\hline & Community health & 1 & 5 \\
\hline & Medical-surgical and noninvasive mechanical ventilation & 1 & 5 \\
\hline & Medical-surgical, intensive care, and emergency & 2 & 10 \\
\hline & Medical-surgical, management, and emergency & 1 & 5 \\
\hline & Medical-surgical, emergency, and trauma & 1 & 5 \\
\hline & None & 6 & 30 \\
\hline \multirow{3}{*}{$\begin{array}{l}\text { Nursing } \\
\text { Duty Time }\end{array}$} & Less than 10 years & 6 & 30 \\
\hline & 10 to 19 years & 4 & 20 \\
\hline & 20 or more years & 10 & 50 \\
\hline \multirow{3}{*}{ ICU Duty Time } & Less than 5 years & 9 & 45 \\
\hline & 5 to 9 years & 2 & 10 \\
\hline & 10 or more years & 9 & 45 \\
\hline
\end{tabular}


All claim to possess knowledge in the area of VAP prevention, $85 \%$ rated their knowledge as good, $73.7 \%$ reported having acquired this training in the context of duty, and the same percentage says that such training took place during the last year (Table 2).

Table 2

Distribution of participants regarding the perception of knowledge on VAP, training, type, and date of training in the area of VAP prevention $(n=20)$

\begin{tabular}{|c|c|c|c|}
\hline & & $N$ & $\%$ \\
\hline \multirow{2}{*}{$\begin{array}{l}\text { Knowledge of VAP } \\
\text { prevention }\end{array}$} & Yes & 20 & 100 \\
\hline & No & 0 & 0 \\
\hline \multirow{4}{*}{ Level of knowledge } & Insufficient & 1 & 5 \\
\hline & Sufficient & 1 & 5 \\
\hline & Good & 17 & 85 \\
\hline & Excellent & 1 & 5 \\
\hline \multirow{2}{*}{$\begin{array}{l}\text { Training in VAP } \\
\text { prevention }\end{array}$} & Yes & 19 & 95 \\
\hline & No & 1 & 5 \\
\hline \multirow{5}{*}{ Type of training } & On-duty training & 14 & 73.7 \\
\hline & Academic training & 2 & 10.5 \\
\hline & On-duty, academic, and in-congress training & 1 & 5.3 \\
\hline & On-duty, in-congress, and in-seminar training & 1 & 5.3 \\
\hline & On-duty, academic, in-congress, and in-seminar training & 1 & 5.3 \\
\hline \multirow{2}{*}{ Date of training } & Last year & 14 & 73.7 \\
\hline & Less than 3 years & 5 & 26.3 \\
\hline
\end{tabular}

One hundred and two observations were made in total, the number of observations per nurse ranged between two and 12, having been registered an average of five observations per nurse. To facilitate the interpretation of the results of the several items that constitute the observation grid, they are divided into three parts: general measures for VAP prevention, hand hygiene, and aspiration of secretions.
The analysis of Table 3 notes, based on the 102 observations, that the majority of the procedures were performed almost in their entirety. The couch lift was not completed, due to contraindication for abdominal surgery; neither was the oral hygiene in two patients, one of them due to nasal packing; and the ventilatory circuits in a patient and the cuff pressure were not checked in $11(10.8 \%)$ patients.

Table 3

Distribution of procedures of general measures of PAV prevention (interventions bundle; $n=102$ )

\begin{tabular}{lccc}
\hline & & $N$ & $\%$ \\
\hline Lifting of bed headboard between $35^{\circ}-40^{\circ}$ & Yes & 101 & 99 \\
\hline Oral hygiene with chlorhexidine gluconate 1x per shift & No & 1 & 1 \\
\hline Maintaining ventilatory circuits clean. Substituting them only when visibly & Yes & 100 & 98 \\
soiled or not working & No & 101 & 99 \\
\hline The cuff pressure is measured 1x per shift, keeping between $20-30 \mathrm{~cm} \mathrm{H} \mathrm{H}_{2} \mathrm{O}$ & Yes & 91 & 89.2 \\
& No & 11 & 10.8 \\
\hline
\end{tabular}


The analysis of Table 4 notes that the hand hygiene was performed in the majority of the procedures and it was verified that it was not performed in two observations after as- piration of secretions, after contact with the patient, and after the handling of respiratory material/equipment.

Table 4

Distribution of participants by hand hygiene during care provision to the patient with IMV $(n=102)$

\begin{tabular}{lccc}
\hline Hand hygiene & & $N$ & $\%$ \\
\hline Before contact with the patient & Yes & 102 & 100 \\
\hline \multirow{2}{*}{ Before handling respiratory material/equipment } & No & - & 100 \\
\hline \multirow{2}{*}{ Before performing aspiration of secretions } & Yes & 102 & - \\
\hline \multirow{2}{*}{ Before oral hygiene } & No & - & 100 \\
\hline \multirow{2}{*}{ After aspiration of secretions } & Yes & 102 & - \\
\hline \multirow{2}{*}{ After contact with the patient } & No & 102 & - \\
\hline \multirow{2}{*}{ After handling respiratory material/equipment } & Yes & - & 98 \\
& No & Yes & 100 \\
\hline
\end{tabular}

Table 5 shows that the aspiration of secretions was performed in $90.2 \%, 5.9 \%$ of which was done incorrectly because the patient's bed was in horizontal position at the time of the aspiration of secretions. It was not performed at $3.9 \%$. The use of individual protection equip- ment (IPE) during the aspiration of secretions was observed in $95.1 \%$. Sterile gloves were used during the aspiration of secretions in the endotracheal tube in $88.2 \%$ of the observations, while $11.8 \%$ did not use gloves.

Table 5

Distribution of participants by aspiration of secretions during care provision to the patient with $\operatorname{IMV}(n=102)$

\begin{tabular}{llcc}
\hline Aspiration of secretions & & $N$ & $\%$ \\
\hline \multirow{3}{*}{ Only in emergency } & Yes & 92 & 90.2 \\
& No & 4 & 3.9 \\
& Yes, but performed incorrectly & 6 & 5.9 \\
\hline \multirow{2}{*}{ Uses IPE } & Yes & 97 & 95.1 \\
& No & 5 & 4.9 \\
\hline \multirow{2}{*}{ Sterile gloves are used } & Yes & 90 & 88.2 \\
& No & 12 & 11.8 \\
\hline
\end{tabular}


The data provided by the GCL - PPCIRA of ULSNE regarding the ICU allow assessing the VAP frequency in the period in which this study was carried out. This analysis notes the diagnosis of two new VAP cases in a universe of 634 patients/intubated/day/month corresponding to a rate of $0.3 \%$. The isolated pathogens were Pseudomonas aeruginosa, Enterobacter and Klebsiella pneumoniae.

\section{Discussion}

This study's sample is composed of 20 nursing professionals, predominantly female (75\%), aged between 30 and 39 years $(50 \%)$, thus corresponding to the profile expected for this area, because the reality of the critically ill patients is attractive to nurses at the beginning of their career.

Concerning academic qualifications, more than half $(70 \%)$ of the sample had advanced training, ranging between specialization, postgraduate degree, and a master's degree. It is worth noting that $30 \%$ report having a very specific expertise in the area of the critical patient: intensive care, medical-surgical and emergency specialization, noninvasive mechanical ventilation (NIV), emergency, and trauma. Thus, it demonstrates the high level of training that the sample holds, which entails a level of more differentiated and specialized knowledge, taking into account the complexity of the interventions carried out in the ICU. This finding corroborates the results of Korhan, Yont, Kiliç, and Uzelli (2013), which identified that the higher the level of education of nursing professionals, the higher their theoretical level about the practices.

As regards the exercise of functions in the ICU, $45 \%$ of the sample is active for less than 5 years. The analysis of this study's data was not able to identify whether there is a relation between the time of experience in the ICU and the level of knowledge, thus showing that the ongoing practice and assimilation by professionals are more important than experience.

The results of Korhan et al. (2013) demonstrated that the time of experience in the ICU did not affect the level of knowledge of nursing professionals, that is, working over a more extended period in this unit does not result in a proportional increase in the scale of knowledge.
As to the characterization of the sample concerning the fruition of knowledge in the area of VAP prevention, the totality of participants replied positively. In what concerns the perception they hold about this degree of knowledge, $85 \%$ reported that they are at a good level. Regarding training in the area of VAP prevention, $95 \%$ responded that they have training, which in their vast majority (73\%) derives from duty time. The last year was when a large part of the sample (73.7\%) acquired/updated the knowledge in this area. "The awareness, the commitment, and the continuing education are key factors for nursing professionals of the ICU to become involved and contribute effectively to the prevention of VAP" (Pombo et al., 2010, p. 1071).

The nursing care for the patient with invasive ventilatory support is the main focus of the research of this study and was explored and identified using a grid of direct observation based on the interventions bundle issued by the DGS (2015), which comprises the recommendations built on scientific evidence. Therefore, it is important to note that the identified and observed nursing care are: lifting of the bed headboard, hand hygiene, aspiration of secretions, oral hygiene, maintenance of ventilatory circuits, and assessment of the cuff pressure. The frequency of support to the bundle of interventions by the sample had high compliance for the six items identified and observed.

The VAP incidence during the period of research was 2 cases in 634 patients/ intubated/ day/month. Currently, the scientific community notes the importance of the practice of nursing care in the prevention of nosocomial infections, particularly in patients with IMV (Gonçalves et al., 2015).

The patient in a supine position for a more extended period represents a significant risk factor for the VAP. The results of this study about the lifting of the bed headboard above $30^{\circ}$ represent a $99 \%$ rate of compliance. This matches the results of other studies in which the lifting of the bed headboard at $30^{\circ}$ benefits the gaseous exchanges of the patient, becoming a factor of VAP prevention, which reduces the possibility of aspiration to $88.9 \%$ (Tonnelier et al., 2005). The patient with a bed headboard position between $30^{\circ}$ to $40^{\circ}$ favors the reduction of gastroesophageal reflux 
and colonization of the oropharynx with the subsequent aspiration of gastric contents. The static supine position promotes a reduction in the transport of ciliary mucus, atelectasis, and altered pulmonary venous flow.

About the care of oral hygiene with chlorhexidine gluconate, practically all professionals performed these once per shift. The maintenance of the ventilatory circuits clean and their replacement only when visibly soiled or not working had, given the observations made, a very high rate of compliance. The result of this significant participation may be explained by the easiness of the technique, as well as the absence of doubt about when and under what conditions they should be substituted. Hinrichsen (2004) emphasizes that the secretions deposited in ventilatory circuits or their inefficient maintenance can lead to the same being aerosolized inside the tracheobronchial tree of the patient or the hands of the professional being soiled, encouraging cross-contamination. With regard to the procedure of the cuff pressure, it had a compliance rate of $89.2 \%$. The lack of adherence to this item of the regulation is because the professionals claimed that the cuff pressure gauge does not allow full permeabilization during measurement, which causes leakage when it is removed, inspiring uncertainty in nurses as to the exact pressure of the cuff. The frequency of measurement must be once per shift, as the not properly inflated balloon can cause necrosis of the trachea or tracheoesophageal fistula. The pressure of the balloon must always remain above $20 \mathrm{~cm} \mathrm{H}_{2} \mathrm{O}$ since an often lower value is associated with the development of pneumonia (Torres, Ewig, Lode, \& Carlet, 2009).

As regards the hand hygiene, high compliance with this procedure occurred in the course of the several procedures. Santos (2004) emphasizes that hand hygiene is considered the most essential and effective care in the prevention and transmission of HAI.

The aspiration of subglottic secretions consists of the removal of secretions, performed in an aseptic way, by a probe connected to a vacuum system, introduced in the endotracheal tube or tracheostomy. This procedure allows keeping the airways open and adequately ventilated, which enables the gaseous exchanges of the patient with IMV.
The aspiration of secretions was performed in $90 \%$ of the observations, however, in $5.9 \%$, the procedure was performed with the patient in a pure dorsal decubitus. This contradicts the rules which stipulate that the patient must be in dorsal decubitus, but with the bed headboard slightly elevated $\left(30-45^{\circ}\right)$, because of the high risk of bronchoaspiration in mechanically ventilated patients (Guérin et al., 2013).

As to the use of IPE, nursing professionals used this prophylactic measure during the aspiration of secretions in 95\%, which denotes an awareness of the IPE for the compliance with this procedure.

However, as regards the use of sterile gloves during the aspiration of secretions, the compliance rate is $88.2 \%$. It is worth emphasizing that the use of sterile gloves is always recommended since the handling of the catheter of tracheal aspiration and its contamination can insert microorganisms in the inferior respiratory tract (Oliveira, Armond, \& Tedesco, 2001).

The main limitations of this study are mostly a short period for data collection and consequently the reduced frequency of observations. Another limitation relates to the fact that the study is carried out in only one ICU, which prevented us from establishing comparisons between units since the study's sample was small.

\section{Conclusion}

This study, over its course, identified a rate of $0.3 \%$ of pneumonia associated with invasive mechanical ventilation. This result shows that nurses from the ICU of ULSNE have a good perception of their knowledge about the fundamental care for VAP prevention. This means they can provide nursing care based on the best scientific evidence, resulting from the continuous training they receive and which are the central element of contribution to the prevention of this infection and the clinical improvement of the patient.

Nevertheless, the verification of the cuff pressure, the patient's position for the aspiration of secretions, and the absence of an aseptic technique for the aspiration of secretions in the orotracheal tube manifested a lower rate of compliance.

Therefore, nursing professionals who provide 
care for critically ill patients must consolidate, renew, and extend their knowledge, through the ongoing formation in duty.

Health professionals should have an ongoing training which focuses on and highlights the crucial importance of meticulous compliance with the bundle as a predictive indicator of better health care provision and favorable evolution for the patient, while avoiding specifically the aspiration of secretions of the patient in pure dorsal decubitus and the use of an aseptic technique in the aspiration of secretions in the endotracheal tube with open system.

The authors suggest the periodic maintenance of current cuff pressure gauges because they regulate the pressure of the cuff transmitted directly into the wall of the trachea, which can lead to injuries. Significant is the risk of bronchoaspiration and, consequently, the occurrence of scenarios of pneumonia caused by incorrect microaspirations due to incorrect insufflation and maintenance of the pressure of the internal balloon, as well as the risk of ischemia and tissue necrosis due to high cuff pressure.

The authors propose that further studies are carried out with larger samples and for longer periods so that associations and inferences can be drawn out for the population in general.

\section{References}

Berwick, D. M. (2014). The 5 million lives campaign. Cambridge, MA: Institute for Healthcare Improvement. Retrieved from http://www.ihi.org/Engage/ Initiatives/Completed/5MillionLivesCampaign/ Pages/default.aspx

Direção-Geral da Saúde. (2015). Norma DGS: "Feixe de intervençōes" de prevenção de pneumonia associada à intubação. Retrieved from https://www.dgs.pt/ directrizes-da-dgs/normas-e-circulares-normativas/ norma-n0212015-de-16122015-pdf.aspx

Direção-Geral da Saúde. (2016). Prevenção e controlo de infeçôes e de resistência aos antimicrobianos em números - 2015. Programa de prevenção e controlo de infeçôes e de resistência aos antimicrobianos. Lisboa, Portugal: Autor.

Gallagher, J. A. (2012). Implementation of ventilator-associated pneumonia clinical guideline (Bundle). The Journal for Nurse Practitioners, 8(5), 377-382.

Gonçalves, F. A., Brasil, V. V., Ribeiro, L.C., \& Tipple, A. F. (2012). Açóes de enfermagem na profilaxia da pneumonia associada à ventilação mecânica. Acta Paulista de Enfermagem, 25(1), 101-7.

Gonçalves, E. O., Lima, M. S., Melo, J. L., Pontes, M. S., Sousa, A. O., \& Albernaz, M. P. (2015). Práticas assistenciais de enfermagem e prevençáo da pneumonia associada à ventilação mecânica em uti. Revista de Enfermagem UFPE, 9(12), 1069-1077.

Guérin, C., Reignier, J., Richard, J-C., Beuret, P., Gacouin, A., Boulain, T. \& Ayzac, L. (2013). Prone positioning in severe acute respiratory distress syndrome. The New England Journal of Medicine, 368(23), 2159-2168.

Guillamet, C. \& Kollef, M. H. (2015). Ventilator associated pneumonia in the ICU: Where has it gone? Current Opinion in Pulmonary Medicine, 21(3), 226-231. doi:10.1097/MCP.0000000000000151

Hinrichsen, S. L. (2004). Biossegurança e controle de infecçóes: Risco sanitário hospitalar. Rio de Janeiro, Brasil: Medsi.

Institute for Healthcare Improvement. (2008). Prevenindo a pneumonia associada à ventilação mecânica. Retrieved from http://www.iqg.com.br/pbsp/ img_up/01311363977.pdf

Korhan, E. A., Yont, G. H., Kiliç, S. P., \& Uzelli, D. (2013). Knowledge levels of intensive care nurses on prevention of ventilator-associated pneumonia. British Association of Critical Care Nurses, 19(1), 26-33.

Oliveira, A. C., Armond, G. A. \& Tedesco, L. A. (2001). Procedimentos nas vias respiratórias. In M. A. Martins, Manual de infecção hospitalar: Epidemiologia, prevenção e controle (2 ed. pp. 343-353-9). Rio de Janeiro, Brasil: Medsi.

Padoveze, M. C., Dantas, S. R., \& Almeida, V. A. (Eds.) (2010). Infeçôes hospitalares em UTI. Assistência de enfermagem ao paciente gravemente enfermo ( 2 a ed., pp. 35-48). São Paulo, Brasil: Atheneu.

Pombo, C. M., Almeida, P. C., \& Rodrigues, J. L. (2010). Conhecimento dos profissionais de saúde na Unidade de Terapia Intensiva sobre prevenção de pneumonia associada à ventilação mecânica. Revista Ciência Saúde Coletiva, 15(1), 1061-1072. Retrieved from http://www.scielo.br/scielo.php?pid=S141381232010000700013\&script=sci_abstract\&tlng=pt

Santos, A. A. (2004). Higienização das mãos no controle das infeçöes em serviços de saúde. Retrieved from http:// www.anvisa.gov.br/servicosaude/controle/higieniz acao_mao.pdf

Tablan, O., Anderson, L., \& Besser, R. (2004). Guidelines for preventing health-care-associated pneumonia: Recommendations of CDC and the healthcare infection control practices advisory committee. Health- 
care Infection Control Practices Advisory Committe, 26(53), 1-36.

Tonnelier, J. M., Prat, G., Gal, G. L., Gut-Gobert, C., Renault, A., \& Boles, J. M. (2005). Impact of a nurses' protocol-directed weaning procedure on outcomes in patients undergoing mechanical ventilation for longer than 48 hours: A prospective cohort study with a matched historical control group. Critical Care, 9(2), 83-9.

Torres, A., Ewig, S., Lode, H. \& Carlet, J. (2009). For the European HAP Working Group. Defining, treating and preventing hospital acquired pneumonia: European perspective. Intensive Care Medicine, 35(1), 9-29. doi:10.1007/s00134-008-1336-9 